\title{
Las crisis y la salud
}

Marx descubrió y describió la naturaleza cíclica de las crisis del capitalismo. En la formación económica social del capitalismo las crisis ocurren con determinada regularidad. Así se ha visto alrededor de 1792, cercana a la independencia de los Estados Unidos, en 1907, la que se ha llamado Gran Depresión de 1929 y la más reciente a mitad de la década de los $80 .^{1}$

El aviso estaba dado hace bastante tiempo, en julio de 2008 Ramonet escribió "nos hallamos ante un seísmo económico de inédita magnitud. Cuyos efectos sociales apenas empiezan a hacerse sentir y que detonarán con toda brutalidad en los meses venideros." 2

Así se cumplió. Con la fuerza con que también lo previó Fidel "Por eso no hace mucho tiempo yo advertía igualmente que, como consecuencia de una crisis que estaba a las puertas, los mercados perderían y el poder adquisitivo de nuestros productos se reducirían considerablemente. "3 De modo que la crisis es global nos afectará a todos.

La crisis financiera hará quebrar bancos y empresas; crecerá rápidamente el desempleo, que ya es elevado, aumentará el número de pobres y entre ellos los que alcanzarán la extrema pobreza, esta equivale al aumento de los hambrientos y en consecuencia la salud de muchos millones de personas se verá afectada. Recordemos la sentencia de J.P. Frank en 1790: "la miseria es la madre de todas las enfermedades."

A esta consecuencia de la crisis financiera sobre la salud humana se añade el efecto de la crisis alimentaria: los precios de los alimentos se elevan a ritmo acelerado, cuando aumenta la pobreza. No ha desaparecido el intento de convertir masivamente alimentos en biocombustibles, de hacerse esto, los precios se elevarán más y llegaremos a tener escasez de comestibles.

Todo coincide con las guerras de rapiña que lanzadas sobre mentiras deja la administración saliente de Estados Unidos, y que trata de prolongar al proponerse la ocupación en Irak al menos por tres años más. Esta es otra fuente de agresión a la salud humana, en su más cruda expresión: muerte, mutilación, desequilibrio psíquico. Y esta guerra es expresión de otra crisis, la militar, donde la mayor potencia armada que ha existido en la tierra, no puede ganar la guerra que empezó.

No se vislumbra la solución. Los más ricos se reúnen, de una cena a un informe vacío de iniciativas constructivas, sólo prevén volver a reunirse.

Otras crisis no son discutidas, la energética, la que crea el cambio climático, la de las enfermedades emergentes y reemergentes. 
Todos elementos que conducirán a un verdadero nuevo holocausto para la gran mayoría de la humanidad.

No será así en Cuba, aunque se sumen desastres que llamamos naturales, aunque pueden estar ligados a cambios climáticos de origen antropogénico. Nuestro sistema social y económico atenúa los efectos de estas crisis. Las sufriremos, con la agravante mencionada y un bloqueo sostenido. Pero recuerden que en lo más crítico del Período Especial, no aumentó la mortalidad infantil, indicador emblemático de nuestra salud pública, surgieron los programas de pesquizaje activo, crecieron las misiones internacionalistas y vencimos la neuropatía epidémica.

Esta es una de las grandes diferencias entre socialismo y capitalismo. Por eso celebramos con júbilo el Aniversario cincienta del triunfo de la Revolución, que nos ha dado a todos la Salud Pública Revolucionaria Cubana.

Francisco Rojas Ochoa

\section{REFERENCI AS BI BLI OGRÁFICAS}

1. de Souza Santos B. Lo impensable aconteció. Granma, 30 de septiembre de 2008: 5 .

2. Ramonet I. Le Monde diplomatique en español. Año XII, No. 153, julio 2008: 1.

3. Castro F. Analfabetismo económico. Reflexiones del compañero Fidel. Granma, 27 de octubre de 2008: 2 . 